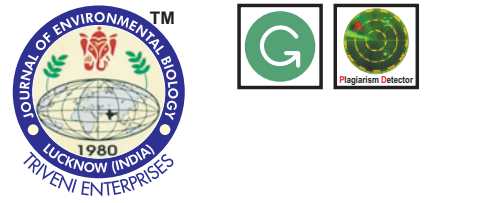

\title{
Forest communities and ecological differentiation of the Mt. Elmacik (Duzce, Turkey)
}

Authors Info

\section{N. Aksoy ${ }^{1 *}$ and S. Coban ${ }^{2}$}

${ }^{1}$ Department of Forestry, Botany and DUOF Herbarium, Faculty of Forestry, Duzce University, Duzce, 81620, Turkey

${ }^{2}$ Department of Silviculture, Faculty of Forestry, Istanbul University, Bahcekoy, Istanbul, 34473, Turkey

*Corresponding Author Email : necmiaksoy@duzce.edu.tr

Key words Bioindication, Diversity, Euro-Siberian, Multivariate techniques, Phytosociology

Publication Info

Paper received : 20.08.2016

Revised received : 15.06 .2017 Accepted : 26.06.2017

\section{Abstract}

Aim : This research is based on vegetation elaboration of Elmacik Mountain in the Western Black Sea Region of Turkey, which has a quite rich floristic and vegetation diversity.

Methodology : Since varied ecological conditions cause a diverse vegetation in the region, vegetationenvironment relation was analyzed with multivariate statistical techniques. In the context of the study, syntaxonomical scheme of the region was introduced and ecological characteristics of the main forest types and vegetation data were analyzed using environmental variables and Ellenberg Indicator Values (EIVs) derived from species composition.

Results : The forest vegetation was presented by 2 classes and 2 orders which contained 4 alliances and 11 associations. Constrained ordination revealed that the altitude is the most important factor affecting species composition (23.1\%), followed by soil depth (19.1\%). However, when conditional effects of variables are considered, forest cover $(16.7 \%)$ had the highest contribution following altitude $(23.1 \%)$. Hyperico calycini-Quercetum petraea had the highest species diversity because of one-storied and light penetrating leaf structure. However, Rhododenro pontici-Fagetum orientalis had the lowest species diversity due to a dense shrub cover consisting of Rhododendron ponticum. Average EIVs for continentality, soil nutrient and light were positively correlated with altitude and nutrient EIVs with soil depth, stand height and cover. Radiation index calculated from latitude, slope degree and aspect showed correlation with light and continentality EIVs.

Interpretation : Altitudinal distribution of forest communities was mainly affected by exposure and soil conditions (soil depth, soil type) in the region. Species variation in each unit was well explained with the average EIVs, which were also supported with the measured environmental variables.

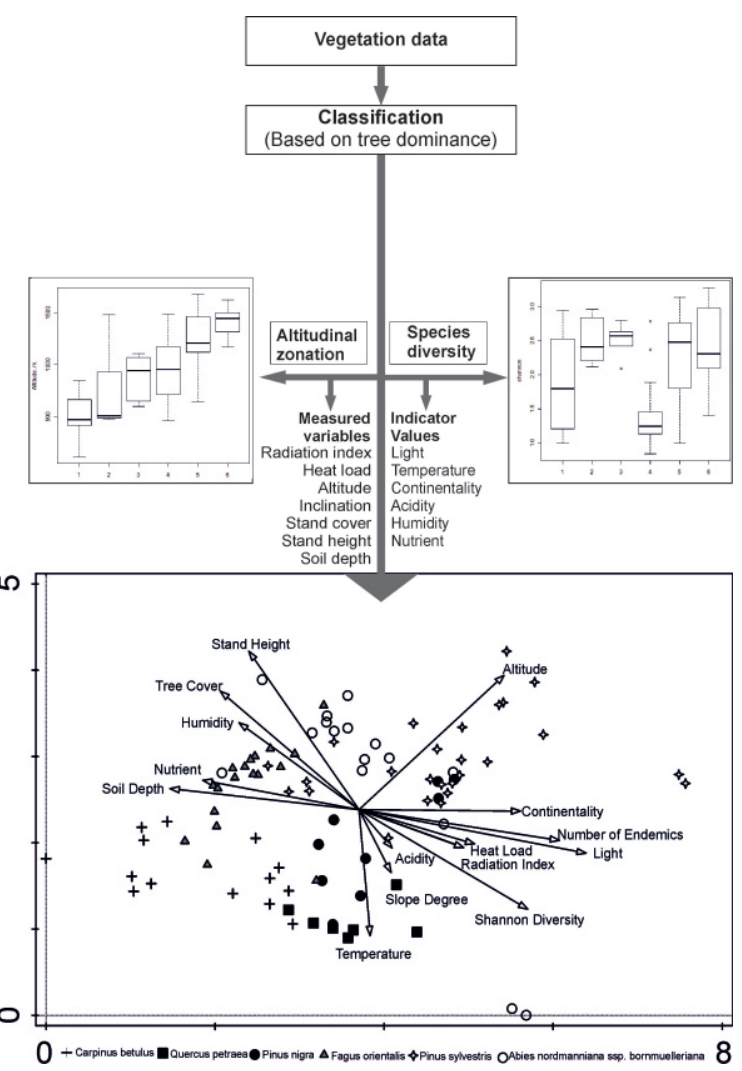




\section{Introduction}

Mountain ecosystems of Turkey support many different vegetation types due to climatic zones and marked changes within short distances. This diversity is also increased with regional differences since Turkey is located at the intersection of three phyto-geographical regions: Euro-Siberian, Mediterranean and Irano-Turanian (Çolak and Rotherham, 2007; Parolly, 2004). Therefore, Turkey has a rich flora in terms of total number of species (c. 12000), and especially the number of endemics (more than 3000$)$ (Efe, 2010; Atalay and Efe 2015).

Turkey can be accepted as a mountainous country with an average altitude of $1132 \mathrm{~m}$ and most of the forests occur in the mountain zones (Atalay and Efe, 2015; Çolak and Rotherham, 2007). For this reason, mountains are very important for conservation of forests and biodiversity besides contributing to the local economy. Current and changing climatic conditions and also human interferences in forest conditions change natural stand structure which ensues forests vulnerable, especially in the mountain ecosystems. Sustainable management of specific forest types requires comprehensive knowledge about mixture combinations, growth relations among species, site condition, climate factors, biological characteristics and competitive ability of species (Çoban and Özalp, 2012).

Phytosociological studies are useful tools for obtaining knowledge about the ecological characteristics of vegetation. In this context, analyzing compositional patterns of plant communities (i.e. indirect ordination analysis and indicator values) and relationship with environmental variables (direct ordination analysis) provide a comprehensive overview of ecological conditions and plant distribution in a region.

The study area, which extends on the western part of the Northern Anatolian Mountain, forms three main orobiomes: humid-temperate broad-leaved deciduous forest belt, humid-cold coniferous forest belt and alpine grassland belt in Euro-Siberian Flora Region. Forest communities of the mountain are classified under two classes and orders: Quercetea pubescentis (Ober, 1948) Doing Kraft.1955, Querco-Fagetea (Braun-Blanquet, 1932; Vliegler, 1937) Fukarek-Fabijanik 1968, QuercoCarpinetalia orientalis Quezel et al. 1980, Fagetalia-Sylvaticae Quezel et al., 1980) containing 4 alliances and 11 associations. In order to reveal underlying ecological conditions of forest communities along altitudinal zones, phytosociological data provide many opportunities since they reflect ecological conditions very well.

The present study was carried out to explore the relationship between forest vegetation and environmental factors as well as plant indicator values to test the efficiency of these parameters for explaining compositional variation in the forest.

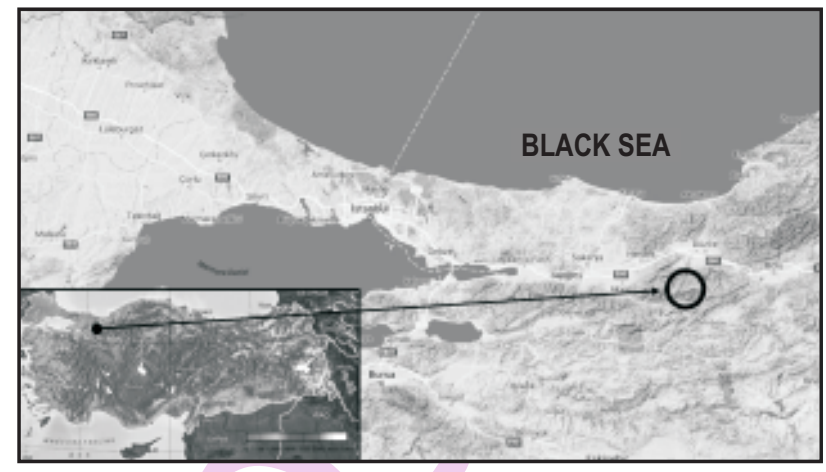

Fig. 1 : Location of the Elmacik Mountain (Google Maps, 2016)

\section{Materials and Methods}

Duzce-Elmacik Mountain is situated between $30^{\circ} 59^{\prime} 121^{\prime \prime}$

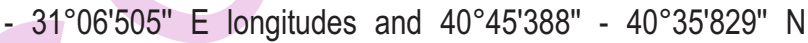
latitudes in the Western Black Sea Region of Turkey. The altitude varies from $100 \mathrm{~m}$ to $1830 \mathrm{~m}$. The study area cover $10387 \mathrm{ha}$. (Fig.1).

The region shows a transitory character between the Mediterranean climate with a very cold, less rainy winter and oceanic climate due to its geographical and topographical characteristics (Aksoy, 2006). Elmacik Mountain is totally closed to the dry southern wind and open to the northern winds, causing a high degree of humidity in the region. Climatic conditions are favorable, as the annual precipitation is about $839.5 \mathrm{~mm}$ and mean annual temperature is $13{ }^{\circ} \mathrm{C}$. The bedrock is mostly composed of Devonian and Paleogene periods originated sediments. Granite, basalt and limestone characteristic rocks occur in the area.

Vegetation data and analysis : Vegetation data of this study were taken from Aksoy (2006). For vegetation analysis of forests, a total of 92 relevés were stored in TURBOVEG (Hennekens and Schaminée, 2001). They were, then transferred to JUICE software (Tichy and Holt, 2006) for further analysis using CANOCO 5 (Šmilauer and Lepš, 2014) and JUICE-R functions. In JUICE software, Ellenberg Indicator Values (EIVs) prepared for Europe were assigned to the species data and weighted by species cover. Finally, average EIVs were obtained for each relevé. Shannon diversity index was calculated for each relevé and each forest type. For the analysis, forest types (based on dominant tree species) were adopted due to few relevés representing some associations. In order to analyze ecological characteristics of the main forest types in terms of measured environmental variables (altitude, inclination, forest cover, soil depth and stand height, number of endemic species, radiation and heat load) Detrended correspondence analysis (DCA) and canonical correspondence analysis (CCA) were used. The aspect of a slope strongly influences the potential direct incident radiation and temperature. For this reason, potential annual direct 


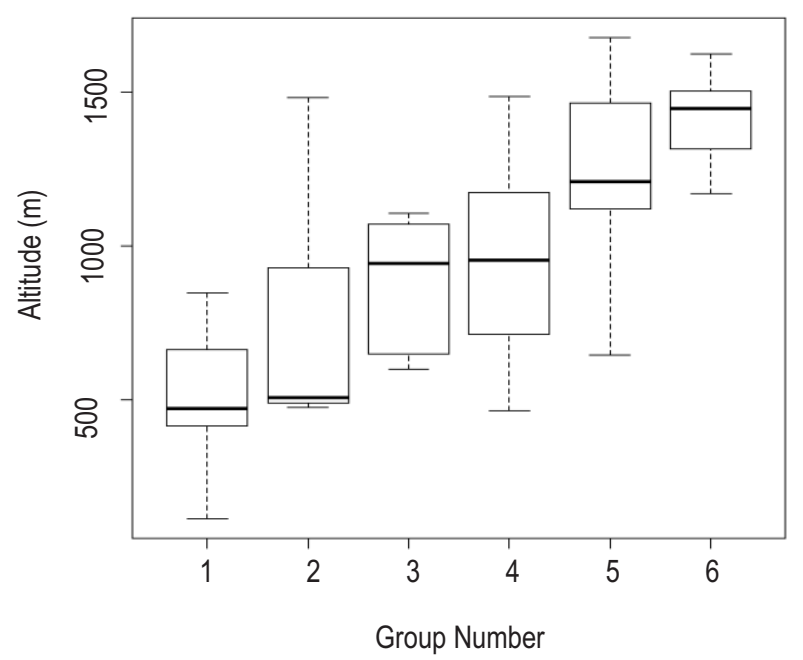

Fig. 2 : Box and Whiskers plots of main forest types (1: Carpinus betulus, 2: Quercus petraea, 3: Pinus nigra, 4: Fagus orientalis, 5: Pinus slyvestris, 6: A. n. ssp. bornmuelleriana dominated forests)

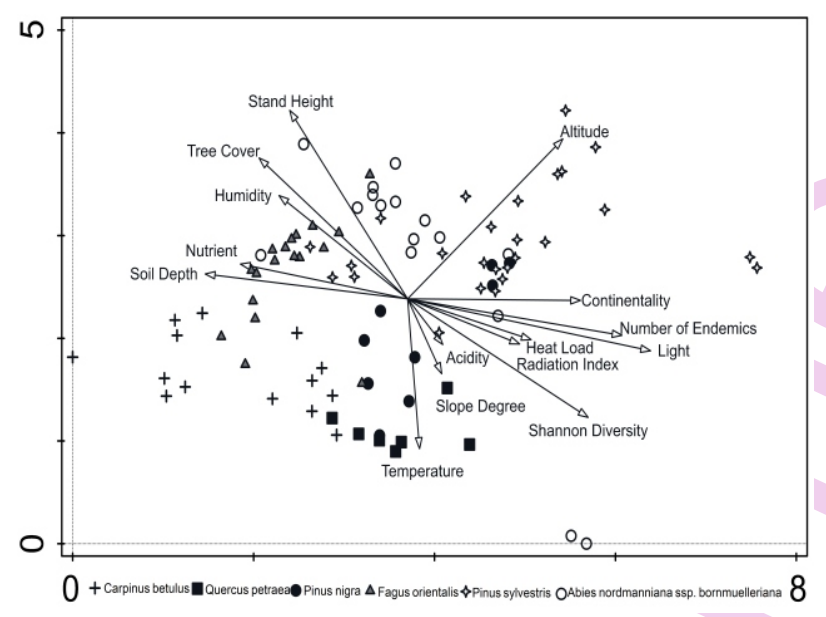

Fig. 3 : Detrended Correspondence Analysis (DCA) of forest vegetation

incident radiation and heat load were calculated from slope, aspect and latitude using equation proposed by McCune and Keon (2002).

\section{Results and Discussion}

Elmacik Mountain had a diverse forest vegetation consisting of pure and/or mixed stands of Carpinus betulus $L$. (Tilio tomentosa-Carpinetum betulus, Buxo sempervirensCarpinetum betuli), Quercus petraea (Matt.) Liebl. (Hyperico calycinum-Quercetum petraea), Pinus nigra J. F. Arnold (Querceto petraea-Pinetum nigra, Genisto tinctoria-Pinetum nigrae, Cisto cretici- Pinetum nigrae), Fagus orientalis Lipsky. (Rhododenro ponticum-Fagetum orientalis, Fago orientalis-
Pinetum sylvestris), Pinus sylvestris L. (Bublero falcato-Pinetum sylvesris, Thlaspio jaubertii-Pinetum sylvesris, Hyperico cerastoidi-Pinetum sylvestris, Taneceto armenum-Pinetum sylvestris) and Abies nordmanniana (Steven) Spach ssp. bornmuelleriana (Matff.) Coode \& Cullen (Rubo hirtus-Abietum bornmueleriana). Its richness derives from the fact that for a huge total number of species ( 631 plant taxa), the number of endemics is considerable (59 taxa). In general, main forest types of the region had a natural distribution sequentially on altitudinal zones. For instance, while northern slopes of the colline zone were covered by broad-leaved forests composed of Tilia argentea DC. and $C$. betulus forest communities, southern slopes with relatively steeper areas were covered with pure or mixed stands of $Q$. petraea and $P$. nigra. Similarly, in high mountain zone, A. n. ssp. bornmuelleriana covered northern and $P$. sylvestris southern slopes. Middle altitudinal zones were mainly composed of $F$. orientalisforests (Fig. 2).

Results of Detrended Correspondence Analysis (DCA), summarized in Fig. 3 showed that vegetation data were heterogeneous (grandient length is 7.57). First two axes explained $10 \%$ of species variation. When the first axis represents a continentality gradient from left to right, second axis was associated with moisture gradient from bottom to top (Fig. 3). Total variation was 11.52 and supplementary variables accounted for $28.2 \%$ of the variation. Altitudinal distribution of forest communities was mainly affected by exposure (heat load and radiation) and soil conditions (soil depth) in the region. This situation was also indicated with average indicator values derived from species composition of sample plots for light and temperature on DCAgraph. In addition, a positive correlation was found between soil depth and average nutrient indicator values. Also, average EIVs for nutrient showed a correlation with stand height and cover. It was shown that southern exposures with shallow soil conditions were dominated by P. nigra and Q. petraea forests which were associated with light, continental, temperate EIVs and also species diversity besides endemism (Fig. 3).

Due to heterogeneous vegetation, unimodal method was used. In Canonical Correspondence Analysis (CCA), all of the considered environmental variables explain together $16.1 \%$ of total variation in species composition. Within this explained variation, altitude was most important factor affecting species composition $(23.1 \%)$, whereas soil depth $(19.1 \%)$ was found to be the second most significant variable. However, when conditional effects of variables were analysed, forest cover (16.7 $\%)$ had the highest contribution following altitude (23.1\%). In the ordination diagram, it was observed that $Q$. petraea and $P$. nigra stands could be developed on steep slopes with shallow soils. However, Q. petreae stands were more competitive on deeper soils compared to $P$. nigra. On the other hand, the nutrient rich site condition was covered by $F$. orientalis and $A$. n. ssp. bornmuelleriana (Fig. 4). 


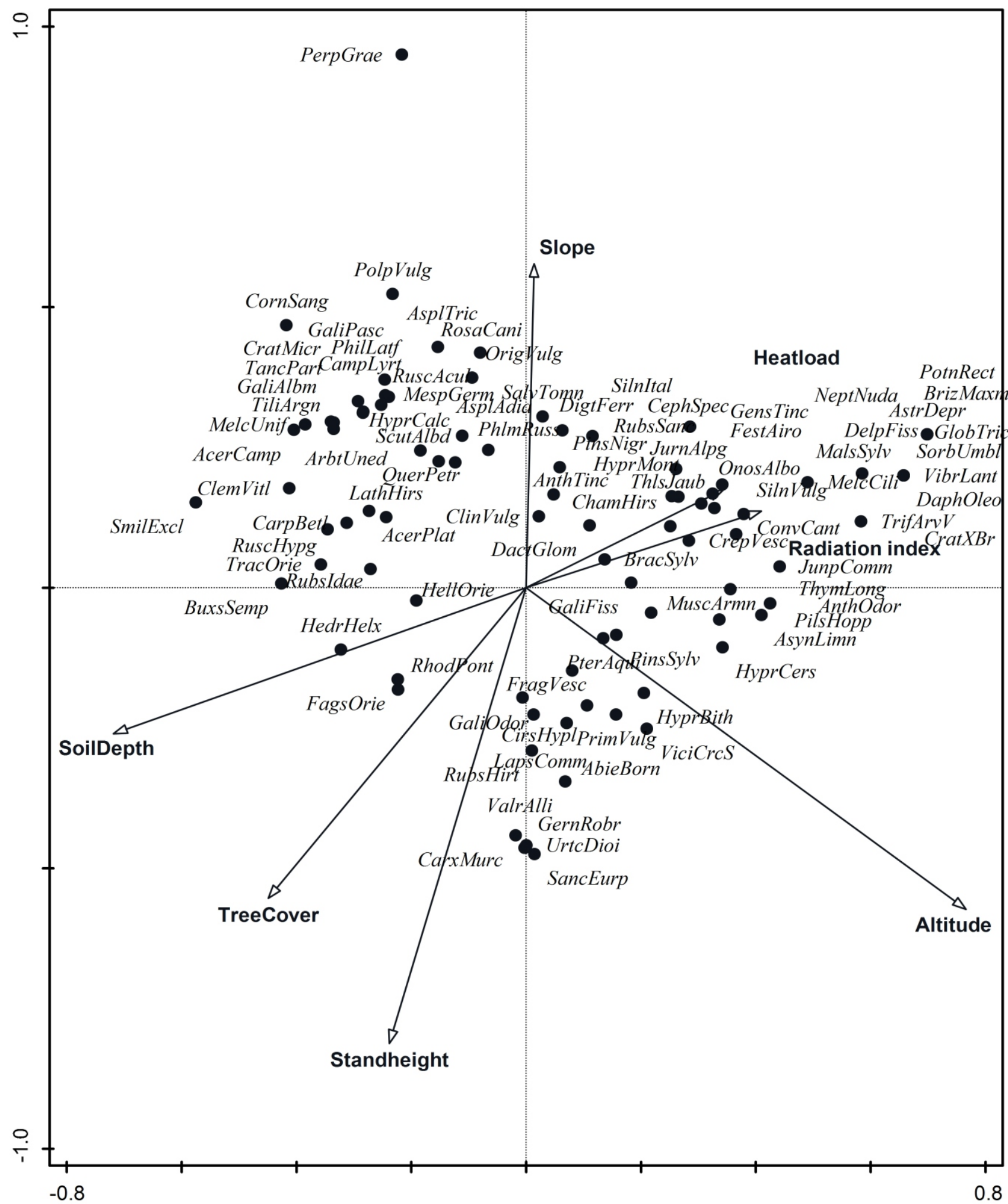

Fig. 4 : Canonical Correspondence Analysis (CCA) of forest vegetation 


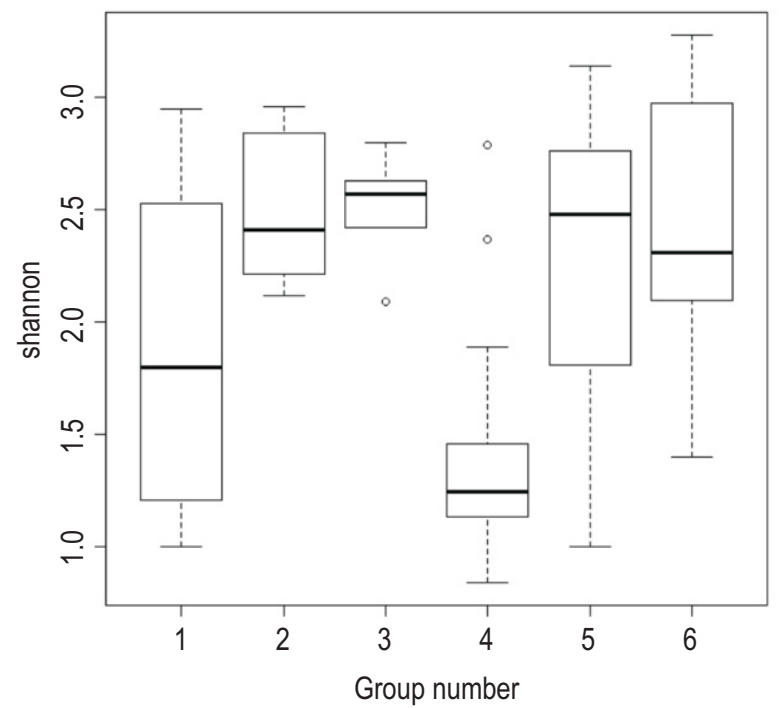

Fig. 5 : Box and Whiskers plots of species diversity of main forest types (1: Carpinus betulus, 2: Quercus petraea, 3: Pinus nigra, 4: Fagus orientalis, 5: Pinus slyvestris, 6: $A$. $n$. ssp. bornmuelleriana dominated forests)

Hyperico calycini-Quercetum petraea had the highest species diversity because of single-storied and light penetrating leaf structure. However, Rhododenro pontici-Fagetum orientalis had the lowest species diversity due to a dense shrub cover consisting of Rhododendron ponticum $L$. It was found that less canopy cover promoted species diversity (Fig. 5).

Average EIVs of relevés for continentality, soil nutrient and light were significantly correlated with the increasing altitude (Fig. 6). While continentality and light EIVs were possitively correlated with altitude, whereas nutrient EIVs were negatively correlated with altitude.
According to Kharkwal et al. (2005), plant community of a region is a function of time as well as altitude, slope, latitude, aspect, rainfall and humidity which play a role in the formation of

community composition. Characteristics of plant communities are affected both by exogenous (i.e. site conditions, animals and human etc.) and endogenous factors (competition and facilitation) (Aksoy 1978). Competition is one of the most important factors affecting coexistence and distribution of plants. However, site conditions considerably affect the competition ability of a species in a plant community and its distribution. The influence of the competition on plant distribution is determined by examination abundances of different plant species in gradients. Similar site requirements of plant species cause a severe competition resulting in exclusion or decreasing abundances of one another. In this respect, small scale heterogeneities in site conditions, i.e., slope, aspect and soil types, enable coexistence of competing plants (MacDonald, 2003). In the study area, measured environmental variables can explain only main ecological conditions along with altitudinal zones. However, detailed information about local climate and soil condition within each altitudinal zones would explain most part of compositional variation.

In this study, ordination of vegetation data with measured environmental parameters showed main factors causing variation in species composition along altitudinal zones. However, all measured variables are not adequate to explain all compositional variation within forest types as the vegetation was too heterogeneous. At this point, indirect ordination and indicator values derived from species composition may help to interpret underlying gradient.

Forest types of the study area can be arranged along different climatic zones and changing ecological conditions in accordance with the altitude. Increasing precipitation and high

\section{A}

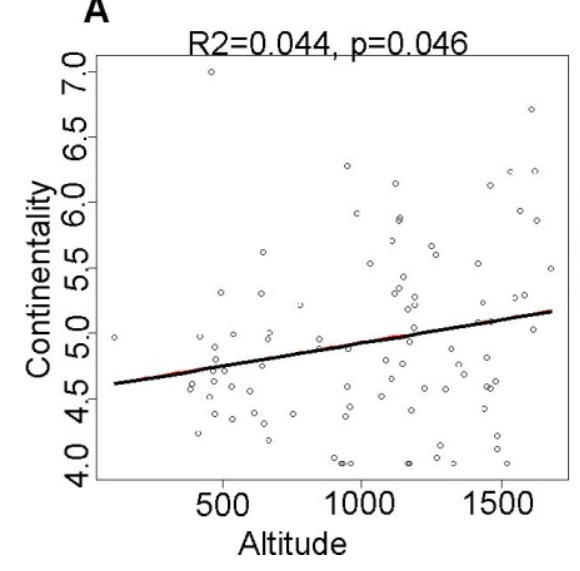

B

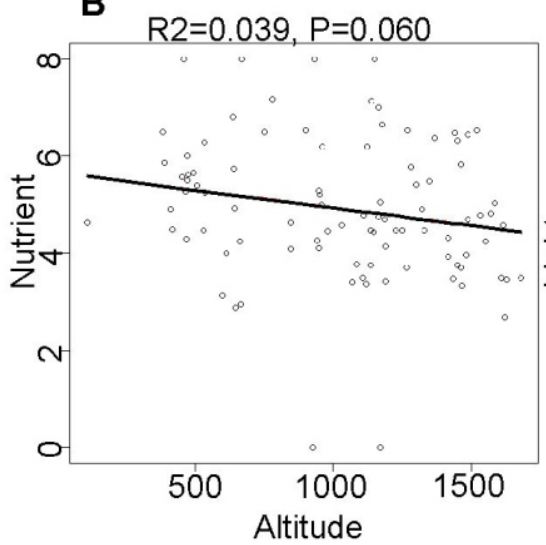

C

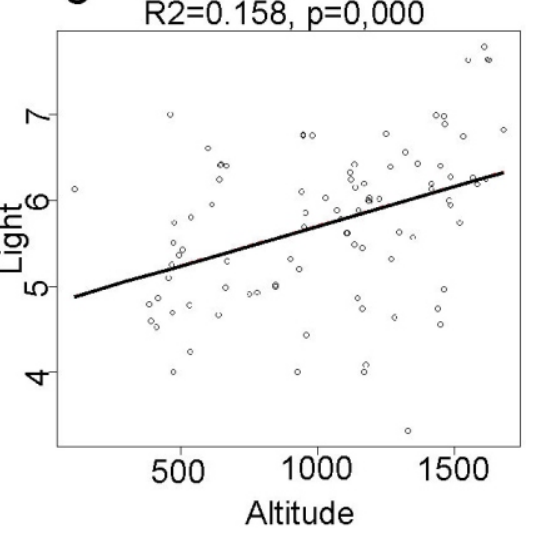

Fig. 6 : Correlation of average indicator values for continentality, nutrient and light with altitude 
atmospheric humidity create favorable conditions for $A$. n. ssp. bornmuelleriana on northern exposures, while these factors show their favorable effects on P. sylvestris dominated forests on southern exposures in upper altitudinal zones. On the other hand, lower altitudinal zone were covered by $F$. orientalis and $C$. betulus on humid site conditions while $Q$. petreae and $P$. nigra occur on drier site conditions, caused by shallow soils and direct radiation. This fact was also confirmed with the average indicator values of relevés. Indicator values system, which has been widely used in vegetation analysis in Europe, is a useful tool to reveal underlying ecological gradient of plant communities, especially when average values of samples are calculated (Ter Braak and Gremmen, 1987; Hill and Carey, 1997; Hawkes et al., 1997; Dzwonko, 2001; Diekmann, 2003; Klaus et al., 2012). However, it is not recommended to use these values instead of measured parameters. But if environmental variables are not adequate, this method can give good information (Çoban, 2016).

Forest communities in the region are important in terms of species diversity and endemic species they contain. It was found that higher species diversity was found in less canopy cover densities, especially on slopes facing southern exposures (showing high radiation and temperature values) because underground gets more light where tree cover is less on drier site conditions. On the other hand, decreasing canopy cover by anthropogenic or natural disturbances promotes development of a dense R. ponticum cover in shrub layer on humid site conditions. According to Çolak (1997), R. ponticum showed invasive characteristics in suitable site conditions due to high competitive ability and prevents the development of other species. In addition, a slight increase was found in species diversity with altitude due to decreasing stand cover within timber line ecotone composed of $A$. $n$. ssp. bornmuelleriana and $P$. sylvestris forests.

\section{Acknowledgments}

The authors would like to thank Prof. Dr. Derya Eşen, Prof. Dr. Süleyman Akbulut, Marijana Novaković-Vuković, Dejan Mandzukovski and Mesut Kuleli for their help and valuable comments.

\section{References}

Aksoy, H.: Karabük-Büyükdüz Araştırma Ormanındaki Orman Toplumları ve Bunların Silvikültürel Özellikleri Üzerine Araştırmalar [Researches on forest communities and their silvicultural characteristics of Karabuk-Buyukduz Research Forest]. İstanbul University publications, No: 2332/237 (1978).

Aksoy, N. and Coban, S.: Diversity and ecological differentiation of forest vegetation in Elmacik Mountain of Duzce, Turkey. 25th International Meeting of the European Vegetation Survey, Book of Abstarct Lectures, p. 12, Roma (2016)

Aksoy, N.: Elmacik Dağı (Duzce) Vejetasyonu [Vegetation of DuzceElmacik Mountain]. Doktora Tezi, İstanbul Üniversitesi Fen
Bilimleri Enstitüsü (2006).

Atalay, I. and R. Efe: Biogeography of Turkey (Türkiye Biyocoğrafyası). Meta Press, Izmir, Turkey (2015).

Braun Blanquet, J.: Plant Sociology. In : The Study of Plant Communities. McGraw-Hill Book Company, inc, New York and London, p. 439 (1932).

Coode, M.J.E. and J. Cullen: Abies Miller. Flora of Turkey, 1, 67-70, (1965).

Çoban, S.: Ecological indicator values of forest communities in Çitdere Region [Yenice-Karabük]. J. Fac. Fores. Istanbul University, 66, 278-287. DOI: 10.17099/jffiu.60821(2016).

Çoban, S. and Özalp, G.: The vegetation analysis of mixed Uludag Fir (Abies bornmulleriana Mattf.) forests in Bolu Ayikaya Region/Turkey. Bartın Orman Fakültesi Dergisi, 14, 62-73 (2012).

Çolak, A. H.: Rhododendron ponticum L. (Mor Çiçekli Ormangülü)'nün Silvikültür Özellikleri Üzerine Araştırmalar [Research on silvicultural characteristics of Rhododendron ponticum L.] Doktora Tezi, İstanbul Üniversitesi Fen Bilimleri Enstitüsü (1997).

Çolak, A. and I. Rotherham: Classification of Turkish forests by altitudinal zones to improve silvicultural practice: a case-study of Turkish high mountain forests. Inter. Fore. Rev., 9, 641-652 (2007).

Diekmann, M.: Species indicator values as an important tool in applied plant ecology-a review. Basic App. Ecol., 4, 493-506 (2003).

Doing, KRAFT, H.: In: De tegenwoordige opvattingen omtrent het associatie-begrip en de systematiek van de plant engezelschappen volgens de method van Braun-Blanquet. Preliminary advice and report of lecture and discussion on meeting of the Kon. Ned. Bot. Ver. (1955).

Dzwonko, Z.: Assessment of light and soil conditions in ancient and recent woodlands by Ellenberg indicator values. J. App. Ecol., 38, 942-951 (2001).

Efe, R.: Biogeography (Biyocoğrafya), MKM Publ, Bursa, Turkey, (2010).

Google Maps, 2016. Map of NW of Turkey. [online]. Google. Available at:https://goo.gl/maps/tyd3KUTgRE72[Accessed 31 March 2016].

Hawkes, J. C., Pyatt, D.G. and White, I.M.S.: Using Ellenberg indicator values to assess soil quality in British forests from ground vegetation: a pilot study. J. App. Ecol., 34, 375-387 (1997).

Hennekens, S. M. and Schaminée, J. H.: TURBOVEG, a comprehensive data base management system for vegetation data. Journal of Veg. Sci., 12, 589-591 (2001).

Hill, M.O. and Carey, P.D.: Prediction of yield in the Rothamsted Park grass experiment by Ellenberg indicator values. J. Vege. Sci., 8, 579-586 (1997).

Kharkwal, G., P. Mehrotra, Y.S. Rawat and Y.P.S. Pangtey: Phytodiversity and growth form in relation to altitudinal gradient in the Central Himalayan (Kumaun) region of India. Curr. Sci., 89, 873-878 (2005).

Klaus, V.H., T. Kleinebecker, S. Boch, J. Müller, S.A. Socher, D. Prati, M. Fischer and N. Hölzel: NIRS meets Ellenberg's indicator values: Prediction of moisture and nitrogen values of agricultural grassland vegetation by means of near-infrared spectral characteristics. Ecol. Indic., 14, 82-86 (2012).

MacDonald, G.M.: Biogeography: Introduction to space, time, and life. John Wiley \& Sons, Inc., New York (2003).

Mccune, B. and D. Keon: Equations for potential annual direct incident radiation and heat load. J. Veget. Sci., 13, 603-606 (2002).

Oberdorfer, E.: Gliederung und Umgrenzung der Mittelmeer vegetation auf der Balkanhalbinsel. Ber Geobot Forschungsinst Rübel Zürich, 1974, 84-111 (1948). 
Parolly, G.: The high mountain vegetation of Turkey-a state of art report, including a first annotated conspectus of the major syntaxa. Turk. J. Bot., 28, 39-63 (2004).

Quézel, P., M. Barbéro and Akman: Contribution `a l'étude la végétation forestiere d'Anatolie septentrionale. Phytocoenologia, 8, 365-519 (1980).

Šmilauer, P. and J. Lepš: Multivariate analysis of ecological data using CANOCO 5. Cambridge university press (2014).

Ter Braak, C. and P. Šmilauer: CANOCO for Windows 4.5. Biometrics,
The Netherlands (2002).

Ter Braak, C.J. and N.J. Gremmen: Ecological amplitudes of plant species and the internal consistency of Ellenberg's indicator values for moisture. Vegetation, 69, 79-87 (1987).

Tichy, L. and Holt, J: JUICE program for management, analysis and classification of ecological data Brno: Vegetation Science Group, Masaryk University (2006).

Vlieger, J.: Aperçu sur les unités phytosociologiques supérieures des PaysBas. Nederlandsch kruidkundig archief. Serie 3, 47, 335-353 (1937). 